Hoyle, L. \& OrR, J. W. (1945). The histogenesis of experimental pneumonics in mice. J. Path. Bact. 57, 441.

IRwIN, J. O. (1951). Note on the relation between LD50 and average time of death in 25 strains of $\boldsymbol{H}$. pertussis. J. gen. Microbiol. 5, 266.

Kendrick, P. L., Elderling, G., Dixon, M. K. \& Misner, J. (1947). Mouse protection tests in the study of pertussis vaccines. Amer. J. publ. Hlth, 37, 803.

KeOGH, E. V. \& North, E. A. (1948). The haemagglutinin of Haemophilus pertussis. 1. Haemagglutinin as a protective antigen in experimental murine pertussis. Aust. J. exp. Biol. med. Sci. 26, 315.

LAPIN, J. H. (1943). Whooping Cough. Springfield, Ill., U.S.A.: Chas. C. Thomas.

Leslie, P. H. \& Gardner, A. D. (1931). The phases of H. pertussis. J. Hyg., Camb., 31, 423.

Miles, A. A. \& Misra, S. S. (1938). The estimation of the bactericidal power of the blood. J. Hyg., Camb., 38, 732.

Norton, J. F. \& Dingle, J. H. (1935). Virulence tests for typhoid bacilli and antibody relationships in antityphoid sera. Amer. J. publ. Hlth, 37, 803.

Proom, H. (1947). The immunological aspects of experimental Haemophilus pertussis infection. J. Path. Bact. 59, 165.

Reed, L. J. \& Muench, H. (1938). A simple method of estimating fifty per cent endpoints. Amer. J. Hyg. 27, 493.

Strean, L. P. (1943). Attempts to enhance the virulence of $H$. pertussis by serial passage in mice. Amer. J. Dis. Child. 65, 895.

Toomey, J. A., Ranta, K. \& Takacs, W. S. (1935). The virulence of $H$. pertussis. J. infect. Dis. 57, 286.

(Received 18 May 1950)

\title{
NOTE ON THE RELATION BETWEEN LD50 AND AVERAGE TIME TO DEATH IN 25 STRAINS OF H. PERTUSSIS
}

\author{
By J. O. IRWIN \\ Medical Research Council Statistical Research Unit, London School of \\ Hygiene and Tropical Medicine, London
}

The values of the LD50 at weekly intervals for 8 weeks are shown in Table 5 (p. 254). Clearly these values vary with the time at which they were calculated. A ratio of 3 to 1 is about significant, judging from Kendrick's tests (1948), and the Table shows greater variations than this at different times. Nevertheless, whenever the LD 50's are calculated they agree very well in the order in which they place the different strains. The coefficient of concordance, which would be unity for perfect agreement in order, is actually 0.85. Accordingly, the strains were classified into five groups of virulence as judged by the LD 50 at 56 days, as follows: less than 1 million; 1 million and less than 5 million; 5 million and less than 25 million; 25 million and less than 125 million; more than 125 million.

Two questions needed answering: (a) Does the relative rapidity of killing at different doses differ significantly in different strains? $(b)$ If so, are these variations from strain to strain correlated significantly with virulence as judged by the LD 50? The answer to $(a)$ was $Y e s$, and to $(b)$ No. The values of average 
time of death among the dead were examined for some of their differences and ratios. Suppose these averages for doses 100, 10, 1 and 0.1 millions are denoted by $x_{1}, x_{2}, x_{3}$ and $x_{4}$; the following values and their standard errors were calculated for each strain:

$$
\begin{array}{ll}
d_{1}=x_{2}-x_{1}, & r_{2}=d_{2} / l_{2}, \\
d_{2}=x_{4}-x_{1}, & l_{1}=\frac{1}{2}\left(x_{2}+x_{1}\right), \\
r_{1}=d_{1} / l_{1}, & l_{2}=\frac{1}{2}\left(x_{4}+x_{1}\right) .
\end{array}
$$

The strains showed significant differences in $d_{1}$ and $d_{2}$ and in $r_{1}$ and $r_{2}$, but the average values of these quantities in the five virulence groups did not differ significantly. Further, there was no significant correlation between $d_{1}$ and $d_{2}$, or between $r_{1}$ and $r_{2}$. A high difference or ratio means that the strain kills relatively much more rapidly at the higher of the two doses compared. Table 1 shows the results in full.

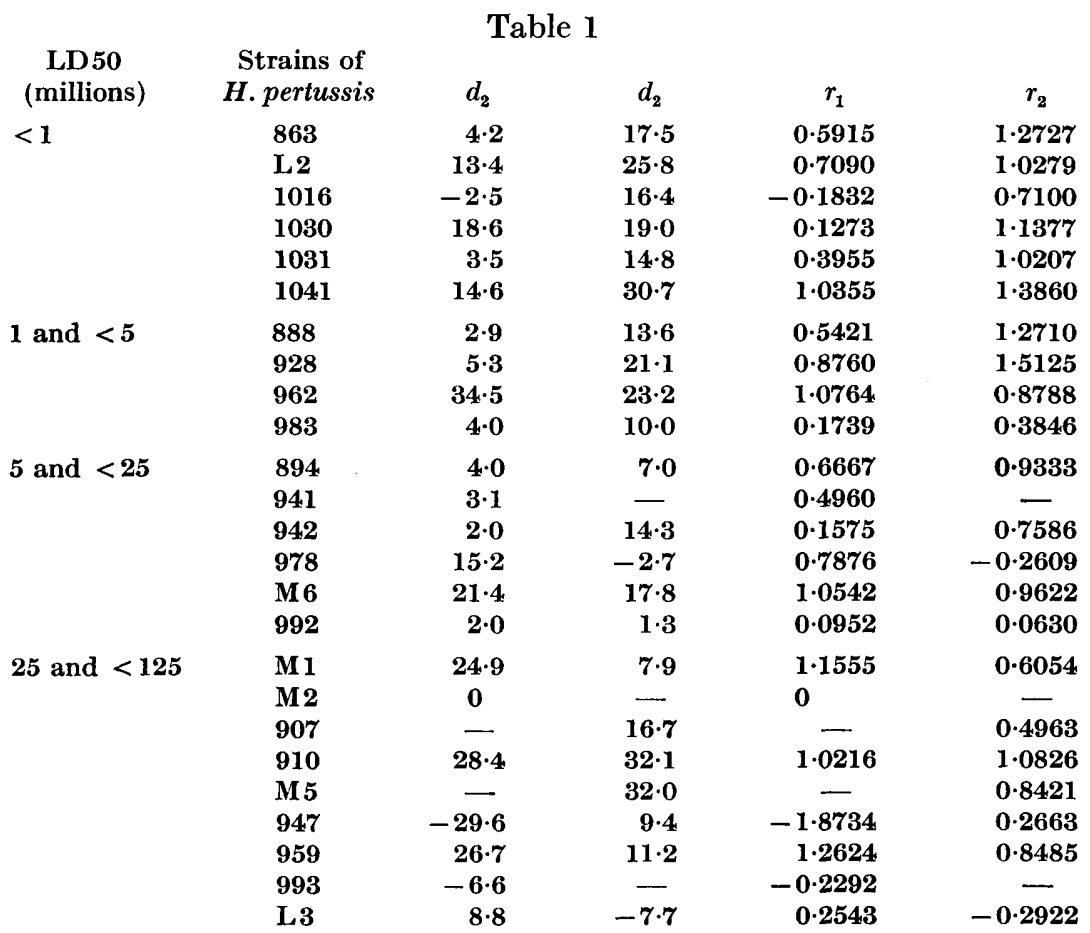

Evidently the strains do show differences in relative rapidity of killing at different doses, but the precise nature of the differences is not very clear.

\section{REFERENCE}

Kendrick, P. L. (1948). Private communication. 